Article

\title{
The Use of Red Shade Nets Improves Growth in Salinized Pepper (Capsicum annuum L.) Plants by Regulating Their Ion Homeostasis and Hormone Balance
}

\author{
Amparo Gálvez ${ }^{1}$, Alfonso Albacete ${ }^{1,2, * \mathbb{C}}$, Francisco M. del Amor ${ }^{1}$ and Josefa López-Marín ${ }^{1}$ \\ 1 Department of Plant Production and Agrotechnology, Institute for Agri-Food Research and Technology of \\ Murcia (IMIDA), C/Mayor s/n, E-30150 Murcia, Spain; amparo.galvez@carm.es (A.G.); \\ franciscom.delamor@carm.es (F.M.d.A.); josefa.lopez38@carm.es (J.L.-M.) \\ 2 Department of Plant Nutrition, Centro de Edafología y Biología Aplicada del Segura (CEBAS-CSIC), \\ Campus Universitario de Espinardo, E-30100 Murcia, Spain \\ * Correspondence: alfonsoa.albacete@carm.es; Tel.: +34-968-36-6762
}

Received: 15 October 2020; Accepted: 9 November 2020; Published: 12 November 2020

check for updates

\begin{abstract}
The actual climate crisis scenario is aggravating the abiotic stress episodes that crop plants have to face. Salinity is one of the most important abiotic stresses directly impairing plant growth and productivity. Several strategies have been developed to minimize the negative effects of salinity in agricultural industry, mainly at the plant level, while management strategies, such us the control of microclimate conditions and light quality over plant canopy, have also been used. Indeed, shading plants with photoselective nets has been considered an efficient management strategy to modulate solar radiation to improve crop productivity. The aim of this work was to gain insights about the physiological factors underlying the salinity-alleviating effect of using red shading nets. For that, pepper plants (Capsicum annuum L.) were grown under control $(0 \mathrm{mM} \mathrm{NaCl})$ and moderate salinity $(35 \mathrm{mM} \mathrm{NaCl})$ conditions, with half of the plants covered with a red net (30\% shading). The shoot growth impairment provoked by salinity was in part minimized by shading plants with red nets, which can be explained by their higher capacity to exclude $\mathrm{Na}^{+}$, control of $\mathrm{K}^{+}$homeostasis and regulation of hormonal balance. Indeed, the concentrations of the most active cytokinin in pepper, trans-zeatin, as well as its metabolic precursor, zeatin riboside, increased in shaded plants, associated to shoot growth recovery and photosynthetic rate maintenance under salinity. Furthermore, the stress-related hormone abscisic acid (ABA) increased with salinity but in a lower extend in the plants shaded with red nets, suggesting a fine tune of stomata opening by ABA which, in crosstalk with salicylic acid increment, improved plant water relations. Likewise, the concentrations of gibberellins and the ethylene precursor, 1-aminocyclopropane-1-carboxylic acid, also changed during salinity stress in shaded plants but those changes were uncoupled of growth responses as indicated by the principal component analysis and thus they seem to play a minor role. Our data demonstrate that shading pepper plants with red nets is an efficient management strategy to modulate microclimate conditions at crop level thus controlling the ion homeostasis and hormonal balance of the plant to cope with salinity stress. This is especially important due to the actual and expected changes of the global climatic conditions.
\end{abstract}

Keywords: pepper; red net; salinity; ion homeostasis; potassium; plant hormones; cytokinins; abscisic acid 


\section{Introduction}

The need of feeding an increasing world's population together with the environmental threatens provoked by the climate change, have changed the actual cultivation paradigm, entailing crop production in marginal soils with high salinity levels. This is contributing to maintain food supply but has a very high environmental cost, aggravating water and soil salinity problems [1], especially in the Mediterranean basin. In fact, salinity is one of the most important abiotic constrains in arid and semiarid areas [2], provoking a high yield gap worldwide [3,4]. Plants are affected at morphological, physiological and molecular levels during salinity stress, negatively affecting growth and development and limiting plant productivity [5-8]. Different strategies have been established at plant and/or agrotechnological levels to cope with salinity stress and improve crop productivity [9]. Shading has been used as an efficient technology to mitigate the extreme climatic fluctuations and pest incidence in arid and semiarid areas and to improve water use efficiency (WUE) while maintaining photosynthesis [10-13]. The use of novel shading nets, with specially-designed optical properties that can alter both the quality and the quantity of the light intercepted in addition to providing the desired protection, represents an efficient approach to manage solar radiation which has been demonstrated to improve crop production $[14,15]$. Different studies have dealt with colored nets in fruit crops (reviewed by Reference [13]) and vegetables (reviewed by Reference [15]). Colour shading nets provoke differential stimulation of some physiological processes that are directly regulated by light, such as photosynthesis and photomorphogenesis. Radiation characteristics are perceived by biological photoreceptors, mainly phytochromes, phototropins and cryptochromes, and their effects on different physiological and stress responses are largely driven by red/far-red (600-800 nm), green/yellow $(500-600 \mathrm{~nm})$ and UV-A/UV-B/blue $(280-500 \mathrm{~nm})$ wavelengths of the electromagnetic spectrum [16]. Phytochrome mutants in the model plant Arabidopsis thaliana have reduced biomass due to lower $\mathrm{CO}_{2}$ assimilation but a higher adaptability to abiotic stress conditions [17,18]. Phototropins, activated by blue light and UV receptors have also shown to play important roles in abiotic stress responses [19-21]. The primary photosynthetic pigments in higher plants, chlorophylls $a$ and $b$, have different absorption patters but both with peaks in the blue $(430-470 \mathrm{~nm})$ and red regions $(660-680 \mathrm{~nm})$ and have very little absorption in the green region. Thus, photosynthesis and overall crop productivity could be enhanced by increasing the amount of blue and red light present in the growth environment $[15,22,23]$.

Considering the different types of colored nets, black nets have been demonstrated to improve WUE and fruit quality in different fruit and vegetable crops, while pearl and yellow nets improved antioxidant activity, fruit yield and quality $[13,15]$. Likewise, the use of red nets induced greater fruit set in peach and apple, relative to other color nets and to un-netted controls [24], while a rapid development of the root system of banana plug transplants during hardening has been associated to the use of red net-covered plants when compared to the commercial black nets [25]. In 'Valencia' orange trees cultivated under top red netting, productivity was improved, as determined by fruit number, fruit size and overall yield [26]. In vegetable crops, plant productivity and quality have been also demonstrated to increase under shaded red nets $[15,27,28]$. In tomato, photoselective red screen combined with optimum plant density promoted higher yield and commercial quality of the fruits $[29,30]$. Importantly, previous works testing sweet pepper under different photoselective nets, have shown that red nets produced the highest intrinsic WUE and reproductive-to-vegetative ratio [14] and induced higher growth and development and whole productivity [28], while in bell pepper the use of red net improved yield [27] and physical quality characteristics and the antioxidant contents with respect to the black net [31].

Plant hormones regulate multiple physiological and regulatory processes in the plant as well as responses to biotic and abiotic stresses. Pioneer studies regarding the modulation of hormonal balance under salinity stress (apart from the "classical ABA") have shown a complex regulatory network among different hormonal classes in controlling growth and senescence [32-34]. Direct evidences of the role of plant hormones in improving growth and yield stability under salinity have appeared in the last years (reviewed by Albacete et al. [4]). For example, Ghanem et al. [35] demonstrated that enhancing 
root cytokinin (CK) synthesis in tomato plants modified both shoot hormonal and ionic status, thus ameliorating salinity-induced decreases in growth and yield. Furthermore, the interaction of the active $\mathrm{CK}$, trans-zeatin (tZ), with ethylene through its precursor, 1-aminocyclopropane-1-carboxylic acid (ACC), explained the strong increase in fruit yield of transgenic plants overexpressing CIN1 gene, that encodes cell wall invertase, a key enzyme in controlling sucrose unloading in tomato fruits [36]. Recent studies have also demonstrated that gibberellins (GAs) play a critical role in regulating growth under salinity conditions [37], while jasmonic acid (JA) and salicylic acid (SA) have been described to play a role in the osmotic stress signaling responses, mainly in interaction with ABA [38,39].

By exogenous application of plant growth regulators, the plant-growth effect of photoselective nets through the modulation of the hormonal balance have been evidenced. For example, Santos et al. [29] showed that spraying paclobutrazol, which belongs to the triazole family and have been shown to reduce GA and increase CK concentrations, impaired growth of tomato seedlings growing under red nets. Also, it has been considered that colored nets are able to replace the effect of plant regulators and other hormone analogues [40]. However, although controlling light intensity and quality through photoselective nets could be an efficient management strategy to cope with salinity stress, so far, there are no direct evidences in literature of the physiological and regulatory mechanisms implicated. Furthermore, as stated before, shading red nets have been shown to be very effective in improving growth and yield in different fruit and vegetable crops. Therefore, the aim of this work was to determine whether red shading nets can improve growth and productivity under salinity stress in pepper plants, through the regulation of the ionic homeostasis and hormonal balance of the plant.

\section{Materials and Methods}

\subsection{Plant Material, Growth Conditions and Treatments}

Seeds of the commercial pepper (Capsicum annuum L.) hybrid, Gacela F1 (Syngenta Seeds, USA), were germinated and, two weeks after sowing, transferred to $10 \mathrm{~L}$ plastic pots ( $50 \%$ sand, $30 \%$ peat, $20 \%$ vermiculite) and disposed in an arch-shaped multispan greenhouse covered with thermal polyethylene, located at the "Torreblanca" experimental field in Torre Pacheco, Murcia (latitude: $37^{\circ} 45^{\prime} \mathrm{N}$; longitude: $0^{\circ} 59^{\prime} \mathrm{W}$ ). Plants were distributed in rows, with a separation of $40 \mathrm{~cm}$ between plants and $100 \mathrm{~cm}$ between rows. A standard Hoagland nutrient solution was used to irrigate the plants and, 15 days after transplanting, half of the plants started to be irrigated with the Hoagland solution supplemented with $35 \mathrm{mM} \mathrm{NaCl}$, reaching an electrical conductivity of $5.5 \mathrm{mS} \cdot \mathrm{cm}^{-1}$. We selected this salinity treatment on the basis of a previous experiment with different salinity levels, considering that pepper is a moderately sensitive crop to salinity [41,42]. Irrigation requirements were based on the weekly crop evapotranspiration (ETc). The saline solution was drained (between $10 \%$ and $25 \%$ according to solar radiation and evapotranspiration) to maintain a constant salinity level throughout the experimental period.

At the time of the application of the salinity treatment, part of the assay area within the greenhouse was covered with a red net (ChromatiNet ${ }^{\circledR}$ Raschel type, 30\% shading, Polysack Plastic Industries LTD, Nir-Yitzak, Israel) placed $50 \mathrm{~cm}$ over the plant canopy, that was periodically moved up as plants grew. The covered area with red net enclosed a half of the plants subjected to optimal nutrient irrigation and a half of the salinized plants. The assay lasted until all plants reached the fruiting stage. Four experimental blocks with 10 plants per treatment were evaluated. The air temperature and photosynthetically active radiation (PAR) in each experimental unit were monitored during the growing cycle using a Testo 177-T4 temperature data logger (Testo SE \& Co. KGaA, Lenzkirch, Germany) and a quantum sensor (LI-COR Inc., Lincoln, NE, USA), respectively.

\subsection{Plant Growth-Related Determinations}

Plant growth-related parameters were recorded at the end of the experiment in 15 plants per treatment. Plant height was determined with a measuring tape and then root, shoot and leaves within 
each shoot were separated to determine their fresh weight (FW). A part of each leaf and root was oven-dried $\left(60^{\circ} \mathrm{C}\right.$ under constant weight) to determine dry weight (DW).

\subsection{Gas Exchange Measurements}

Gas-exchange was monitored in fully expanded leaves at the plant vegetative stage. Measurements

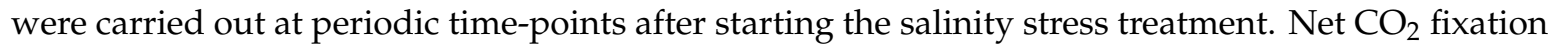
rate $\left(A_{\max }, \mu \mathrm{mol} \mathrm{CO} \mathrm{CO}_{2} \cdot \mathrm{m}^{-2} \cdot \mathrm{s}^{-1}\right)$, stomatal conductance to water vapor $\left(\mathrm{g}_{\mathrm{s}}, \mathrm{mmol} \mathrm{H}_{2} \mathrm{O} \cdot \mathrm{m}^{-2} \cdot \mathrm{s}^{-1}\right)$ and transpiration rate $\left(E, \mathrm{mmol} \mathrm{H}_{2} \mathrm{O} \cdot \mathrm{m}^{-2} \cdot \mathrm{s}^{-1}\right)$ were measured in steady-state under conditions of saturating light $\left(800 \mu \mathrm{mol} \cdot \mathrm{m}^{-2} \cdot \mathrm{s}^{-1}\right)$ and $400 \mathrm{ppm} \mathrm{CO} \mathrm{CO}_{2}$ with a LI-6400 instrument (LI-COR, Lincoln, NE, USA).

\subsection{Leaf Water Potential, Osmotic Potential and Relative Water Content}

Water potential $\left(\Psi_{\mathrm{w}}\right)$ was determined in mature leaves using a Scholander type pressure chamber (model 3000, Soil Moisture Equipment Co., Goleta, CA, USA), while osmotic potential $\left(\Psi_{\mathrm{s}}\right)$ was analyzed in leaf extracts with an osmometer (model Vapro 5520, Wescor Inc., South Logan, UT, USA). The relative water content (RWC) was measured using leaf discs of $1 \mathrm{~cm}^{2}$ and calculated according to the following equation: $R W C=[(F W-D W) /(T W-D W)] \times 100$, where $\mathrm{FW}$ is the fresh weight recorded during collection, TW is the turgid weight and DW is the oven dry weight $\left(60^{\circ} \mathrm{C}\right.$ until constant weight). To determine TW, disc leaves were kept in distilled water in darkness at $4{ }^{\circ} \mathrm{C}$ to minimize respiration losses until they reached a constant weight (full turgor, typically after $24 \mathrm{~h}$ ).

\subsection{Chlorophyll Analysis}

Chlorophylls were extracted from $1 \mathrm{~g}$ of frozen pepper leaves $\left(-80^{\circ} \mathrm{C}\right)$ with $25 \mathrm{~mL}$ of acetone/hexane $(2 / 3, v / v)$ solvent. Samples were homogenized and centrifuged at $5000 \mathrm{~g}$ for $6 \mathrm{~min}$ at $4{ }^{\circ} \mathrm{C}$. Subsequently, the optical density of the supernatant was measured spectrophotometrically at wavelengths of 663 and $645 \mathrm{~nm}$. The contents of chlorophylls a and b were calculated according to the Nagata and Yamashita equations [43]:

$$
\begin{aligned}
& \text { Chlorophyll a }\left(m g \cdot 100 m L^{-1}\right)=0.999 \cdot A_{663}-0.0989 \cdot A_{645} \\
& \text { Chlorophyll b }\left(m g \cdot 100 m L^{-1}\right)=-0.328 \cdot A_{663}+1.77 \cdot A_{645}
\end{aligned}
$$

\subsection{Ion Determinations}

Mature leaves were oven-dried at $60^{\circ} \mathrm{C}$ for $48 \mathrm{~h}$ and homogenized with a grinder. Fifty mg were digested at $80^{\circ} \mathrm{C}$ in a $\mathrm{HNO}_{3} / \mathrm{H}_{2} \mathrm{O}_{2}$ solution $(5 / 3, v / v)$. Minerals were dissolved in $0.1 \mathrm{M} \mathrm{HCl}$, diluted with de-ionized water and filtered. Cation concentrations were analyzed using an inductively coupled plasma optical emission spectrometer (ICP-OES, Vista-MPX, Varian, Belrose, Australia) calibrated with certified standard solutions.

\subsection{Hormone Extraction and Analysis}

Cytokinins (trans-zeatin, $\mathrm{tZ}$, zeatin riboside, $\mathrm{ZR}$ and isopentenyl adenine, $\mathrm{iP})$, gibberellins $\left(\mathrm{GA}_{1}\right.$, $\mathrm{GA}_{3}$ and $\mathrm{GA}_{4}$ ), indole-3-acetic acid (IAA), abscisic acid (ABA), salicylic acid (SA), jasmonic acid (JA) and the ethylene precursor 1-aminocyclopropane-1-carboxylic acid (ACC) were analysed according to Albacete et al. [33] with some modifications. Briefly, $50 \mathrm{mg}$ of freeze-dried plant material were dropped in $0.5 \mathrm{~mL}$ of cold $\left(-20^{\circ} \mathrm{C}\right)$ extraction mixture of methanol/water $(80 / 20, v / v)$. Then, $10 \mu \mathrm{L}$ of internal standard mix, composed of deuterated hormones $\left(\left[{ }^{2} \mathrm{H}_{5}\right] \mathrm{tZ},\left[{ }^{2} \mathrm{H}_{5}\right] \mathrm{tZR},\left[{ }^{2} \mathrm{H}_{6}\right] \mathrm{iP},\left[{ }^{2} \mathrm{H}_{2}\right] \mathrm{GA}_{1}\right.$, $\left[{ }^{2} \mathrm{H}_{2}\right] \mathrm{GA}_{3},\left[{ }^{2} \mathrm{H}_{2}\right] \mathrm{GA}_{4},\left[{ }^{2} \mathrm{H}_{5}\right] \mathrm{IAA},\left[{ }^{2} \mathrm{H}_{6}\right] \mathrm{ABA},\left[{ }^{2} \mathrm{H}_{4}\right] \mathrm{SA},\left[{ }^{2} \mathrm{H}_{6}\right] \mathrm{JA},\left[{ }^{2} \mathrm{H}_{4}\right] \mathrm{ACC}$, Olchemim Ltd., Olomouc, Czech Republic) at a concentration of $1 \mu \mathrm{g} \cdot \mathrm{mL}^{-1}$ each, was added to the extraction homogenate. Solids were separated by centrifugation $\left(20,000 \mathrm{~g}, 15 \mathrm{~min}, 4^{\circ} \mathrm{C}\right)$ and re-extracted for $30 \mathrm{~min}$ at $4{ }^{\circ} \mathrm{C}$ in additional $0.5 \mathrm{~mL}$ of the same extraction solution. Pooled supernatants were passed through Sep-Pak Plus $\mathrm{C}_{18}$ cartridges (SepPak Plus, Waters, Milford, MA, USA) to remove interfering lipids and part of plant pigments and evaporated at $40{ }^{\circ} \mathrm{C}$ under vacuum to near dryness. The residue 
was dissolved in $0.5 \mathrm{~mL}$ methanol/water $(20 / 80, v / v)$ solution using an ultrasonic bath. The dissolved samples were filtered through $13 \mathrm{~mm}$ diameter Millex filters with $0.22 \mu \mathrm{m}$ pore size nylon membrane (Millipore, Bedford, MA, USA).

Ten $\mu \mathrm{L}$ of filtered extract were injected in a U-HPLC-MS system consisting of an Accela Series U-HPLC (ThermoFisher Scientific, Waltham, MA, USA) coupled to an Exactive mass spectrometer (ThermoFisher Scientific, Waltham, MA, USA) using a heated electrospray ionization (HESI) interface. Mass spectra were obtained using the Xcalibur software version 2.2 (ThermoFisher Scientific, Waltham, MA, USA). For the quantification of the plant hormones, calibration curves were constructed for each analysed component $\left(1,10,50\right.$ and $\left.100 \mu \mathrm{g} \cdot \mathrm{L}^{-1}\right)$ and corrected for $10 \mu \mathrm{g} \cdot \mathrm{L}^{-1}$ deuterated internal standards. Recovery percentages ranged between 92 and $95 \%$.

\subsection{Statistical Analysis}

The data were tested first for homogeneity of variance and normality of distribution. Analysis of variance and principal component analysis (PCA) were performed using SPSS for Windows (Version 25.0, SPSS Inc., Chicago, IL, USA). Means of different graft combinations were compared using Tukey's test at 0.05 of confidence level and the Varimax method was used for PCA.

\section{Results}

\subsection{Microclimate Conditions}

Shading pepper plants with red nets has a direct effect on microclimate conditions in the growing area, especially temperature and PAR. Our study show that during growing period, the average temperature in the area below the red net was $2.5^{\circ} \mathrm{C}$ lower than in the non-shaded area at the central hours of the day (Figure 1a). The PAR over the plant canopy of one representative day between 13:00 and 14:00 $\mathrm{h}$ had a value of $1904 \mu \mathrm{mol} \cdot \mathrm{s}^{-1} \cdot \mathrm{m}^{-2}$ in the non-shaded area (Figure 1b). By shading the pepper plants with red nets, the PAR was lowered to $1425 \mu \mathrm{mol} \cdot \mathrm{s}^{-1} \cdot \mathrm{m}^{-2}$ (by $35 \%$ ).

(a)

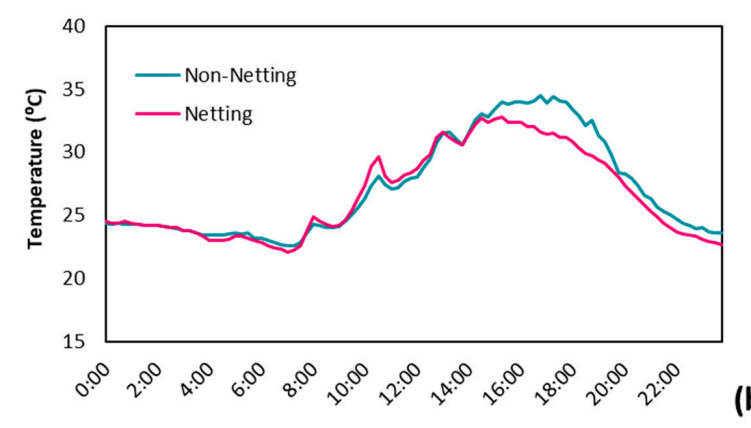

(b)

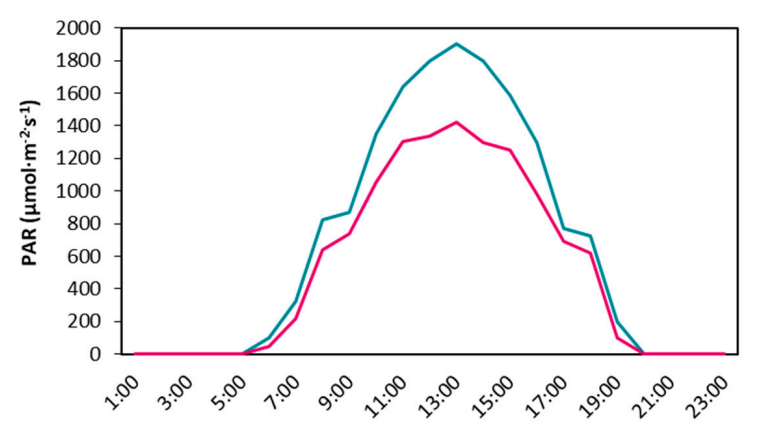

Figure 1. (a) Average temperature and (b) incident photosynthetically active radiation (PAR) during the growing period over the canopy of pepper plants cultivated under control $(0 \mathrm{mM} \mathrm{NaCl})$ and salinity $(35 \mathrm{mM} \mathrm{NaCl})$ conditions and covered or not with red nets. 


\subsection{Plant Growth Parameters}

Plant growth parameters were significantly affected by the use of red nets and salinity application (Figure 2). Using red nets increased shoot FW under both control and salinity conditions but this increment was only significant in salinized pepper plants (by $40 \%$, Figure 2a). Other shoot growth-related parameters were also affected. Leaf FW and plant height significantly increased (by $64 \%$ and $29 \%$, respectively) when using red nets under control and salinity conditions (Figure $2 \mathrm{~b}, \mathrm{c}$ ). In contrast, although salinity reduced root FW, the red nets did not have any significant effect in root growth (Figure 2d).

(a)

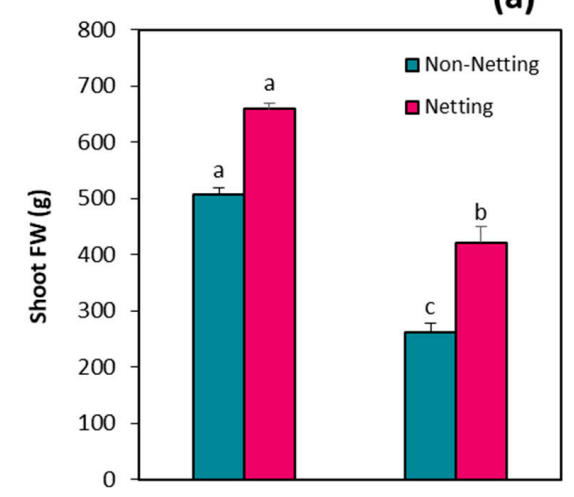

(b)

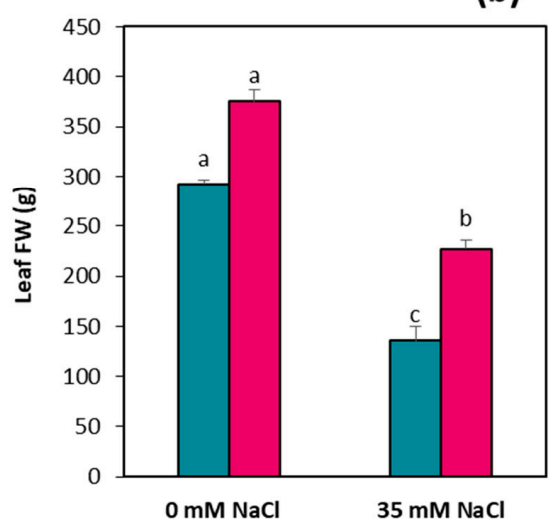

(c)

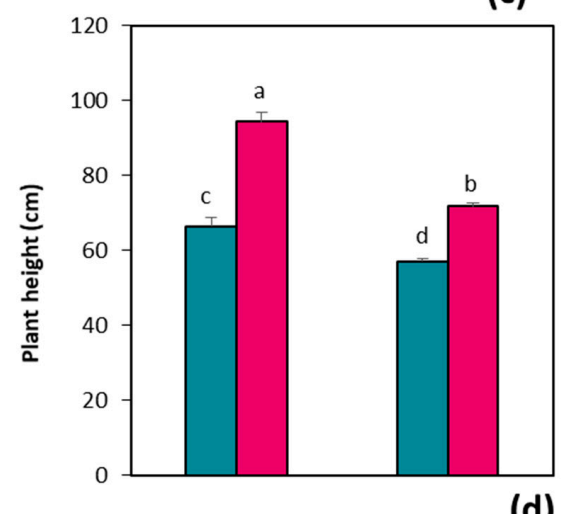

(d)

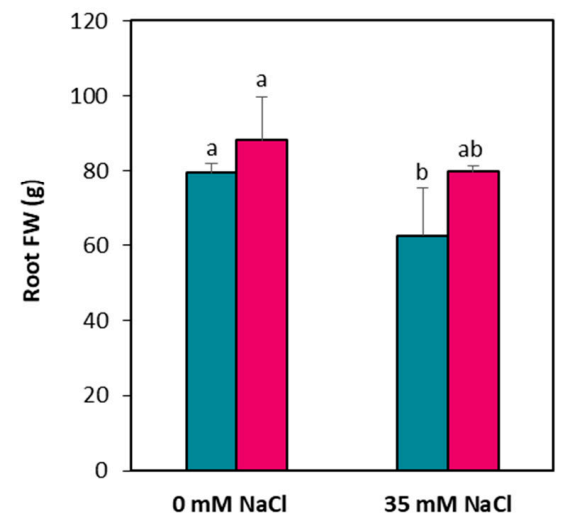

Figure 2. (a) Shoot fresh weight (FW), (b) leaf FW, (c) plant height and (d) root FW of pepper plants cultivated under control $(0 \mathrm{mM} \mathrm{NaCl})$ and salinity $(35 \mathrm{mM} \mathrm{NaCl})$ conditions and covered or not with red nets. Bars show the means of four plants with the standard error. Different letters among bars indicate statistical differences according to Tukey's test $(p \leq 0.05)$.

\subsection{Leaf Gas Exchange Parameters}

In general, all leaf gas exchange-related parameters decreased over the salinity period, except intrinsic WUE, that is a derived parameter (Figure 3). Non-salinized pepper plants subjected to red net shading presented the highest net $\mathrm{CO}_{2}$ assimilation over the whole experimental period, while non-shaded plants grown under salinity conditions showed the lowest photosynthetic rate (Figure 3a). Importantly, under salinity, the use of red nets maintained $\mathrm{CO}_{2}$ assimilation between $35 \%$ and 50\% higher than non-shaded pepper plants (Figure 3a).

Stomatal conductance also decreased over the experimental period. Interestingly, shaded plants under control conditions kept significantly higher conductance than the other treatments, except at the end of the assay (Figure 3b). A similar pattern was observed for the transpiration rate, but, in this case, although not significant, both control treatments (netting and not-netting) separated from the salinized ones (Figure 3c). 
Concerning intrinsic WUE, calculated as the ratio between photosynthetic rate and transpiration rate, an increase over the assay was observed, with significant differences among treatments, especially apparent at the end of the experimental period (Figure 3d). In fact, 50 days after starting the salinity treatment, shaded plants under control and salinity conditions showed significantly higher WUE than non-shaded plants (by $40 \%$ and 2-fold, respectively). Importantly, shaded pepper plants subjected to salinity showed the highest intrinsic WUE (Figure 3d).

(a)

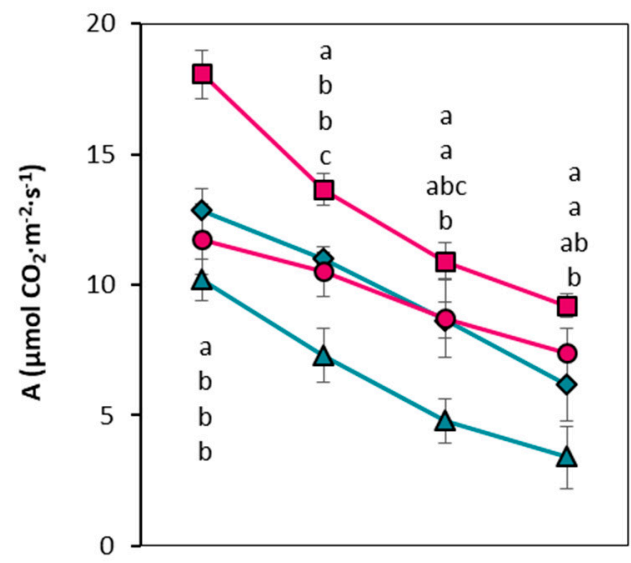

(b)

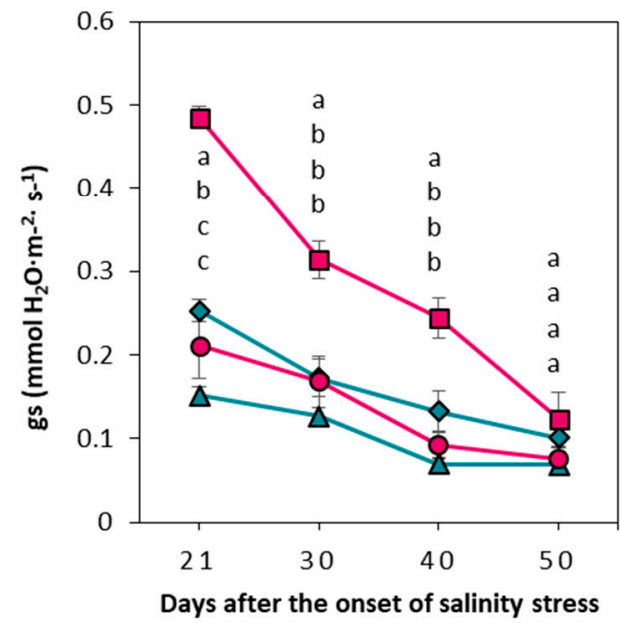

(c)

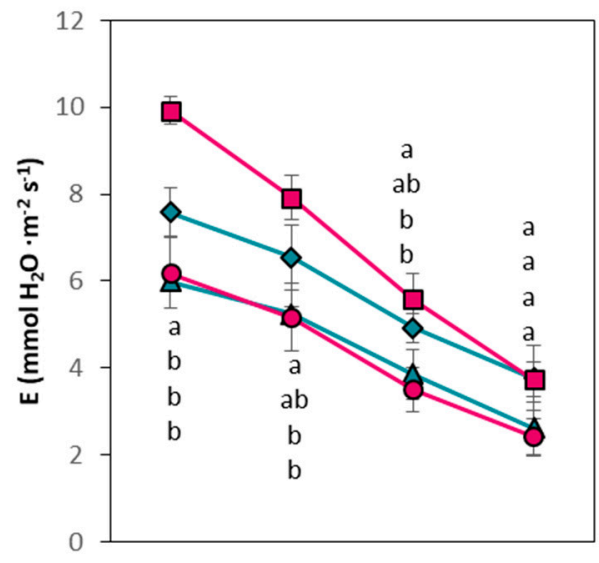

(d)

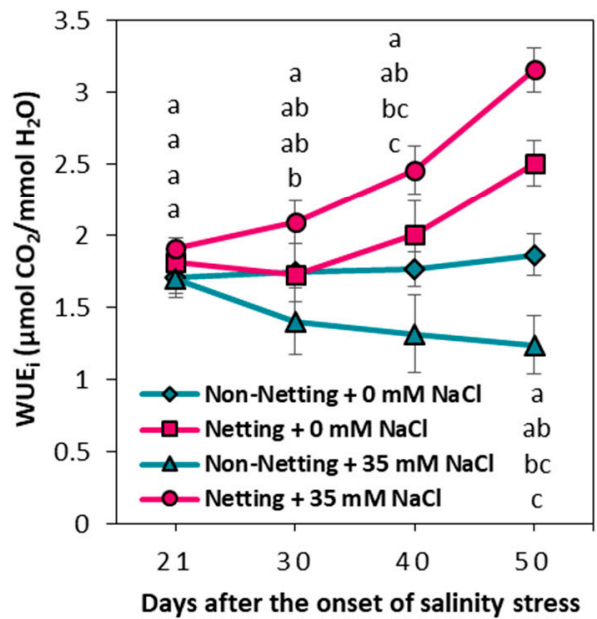

Figure 3. (a) Evolution of photosynthetic rate $(A),(\mathbf{b})$ transpiration rate $(E)$, (c) stomatal conductance $\left(g_{s}\right)$ and $(\mathbf{d})$ intrinsic water use efficiency $\left(W_{U} E_{i}\right)$ in pepper plants cultivated under control $(0 \mathrm{mM}$ $\mathrm{NaCl})$ and salinity $(35 \mathrm{mM} \mathrm{NaCl}$ ) conditions and covered or not with red nets. Data are means of four plants \pm standard error. Different letters within each time-point indicate statistical differences according to Tukey's test $(p \leq 0.05)$.

\subsection{Plant Water Relations}

Leaf water potential decreased with salinity in both shaded and non-shaded plants (Table 1). However, plants grown under red nets showed higher leaf water potential than non-covered pepper plants under both control (by 27\%) and salinity conditions (by 28\%). Similarly, osmotic potential decreased with salinity, being significantly lower in non-netted plants under salinity conditions with respect to the other treatments (Table 1). Importantly, despite relative water content also decreased with salinity, salinized pepper plants grown under red nets presented significantly higher values (Table 1). 
Table 1. Leaf water potencial $\left(\Psi_{\mathrm{W}}\right)$, osmotic potencial $\left(\Psi_{\mathrm{S}}\right)$ and relative water content $(\mathrm{RWC})$ in pepper plants cultivated under control $(0 \mathrm{mM} \mathrm{NaCl})$ and salinity $(35 \mathrm{mM} \mathrm{NaCl})$ conditions and covered or not with red nets.

\begin{tabular}{|c|c|c|c|c|}
\hline Cover $^{1}$ & Salt Treatment ${ }^{1}$ & $\Psi_{\mathrm{w}}(\mathrm{Mpa})$ & $\Psi_{\mathrm{s}}(\mathrm{Mpa})$ & RWC (\%) \\
\hline \multirow{2}{*}{ Non netting } & $0 \mathrm{mM}$ & $-0.74 \mathrm{ab}$ & $-1.76 b$ & $88.80 \mathrm{a}$ \\
\hline & $35 \mathrm{mM}$ & $-0.94 b$ & $-2.04 \mathrm{a}$ & $87.98 \mathrm{ab}$ \\
\hline \multirow{2}{*}{ Netting } & $0 \mathrm{mM}$ & $-0.53 a$ & $-1.64 b$ & 89.33 a \\
\hline & $35 \mathrm{mM}$ & $-0.68 \mathrm{ab}$ & $-1.77 \mathrm{~b}$ & $88.17 \mathrm{~b}$ \\
\hline \multicolumn{5}{|l|}{ ANOVA $^{2}$} \\
\hline Cover & & * & * & * \\
\hline Salinity & & $* *$ & $* *$ & * \\
\hline $\mathrm{C} \times \mathrm{S}$ & & * & * & ns \\
\hline
\end{tabular}

Data are means of four plants. ${ }^{1}$ Different letters within a column indicate significant differences among treatments $(p \leq 0.05) .{ }^{2}$ Analysis of variance: $n s$, not significant; ${ }^{*} p \leq 0.05 ;{ }^{* *} p \leq 0.01$.

\subsection{Chlorophyll Content}

Salinity significantly decreased chlorophyll $a$ content only in non-shaded pepper plants, while the concentrations of this pigment in salinized plants grown under red net were maintained at similar levels to those of control conditions (Figure 4a). However, chlorophyll $b$ and total chlorophyll content $(a+b)$ were significantly reduced by salinity in both shaded- and non-shaded-grown plants (Figure $4 b, c)$. Interestingly, this reduction was lower in plants grown under red net (by 33\% and 15\% for chlorophyll $b$ and total chlorophyll content, respectively) than in non-shaded pepper plants ( $45 \%$ and $35 \%$, respectively), thus shaded plants maintaining significantly higher chlorophyll $a$ and total chlorophyll concentrations under salinity (Figure $4 b, c)$.

(a)
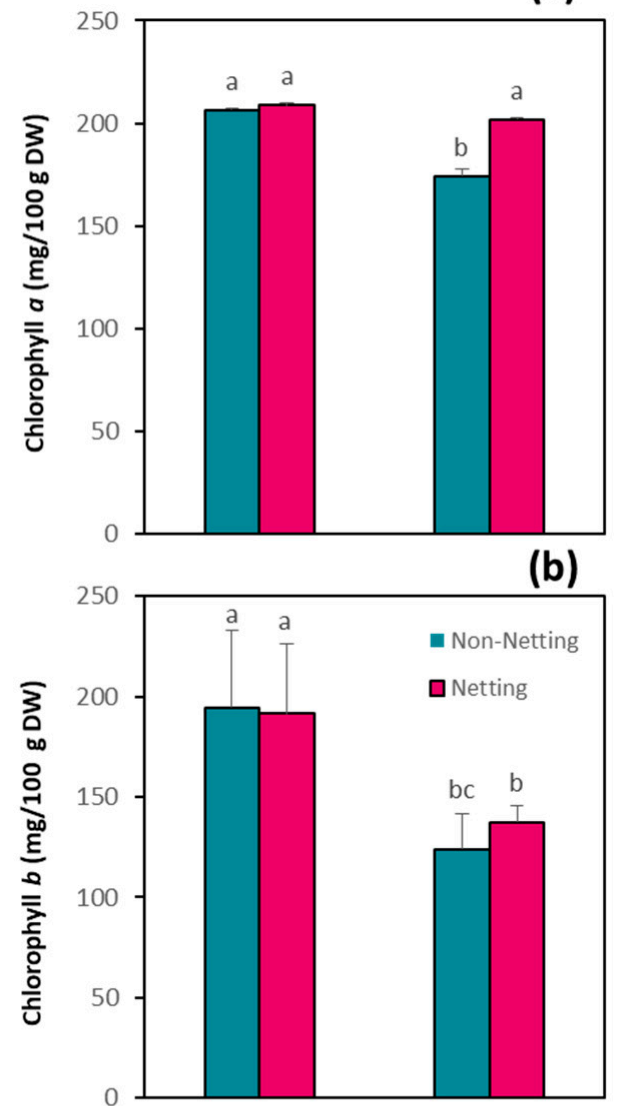

Figure 4. Cont. 


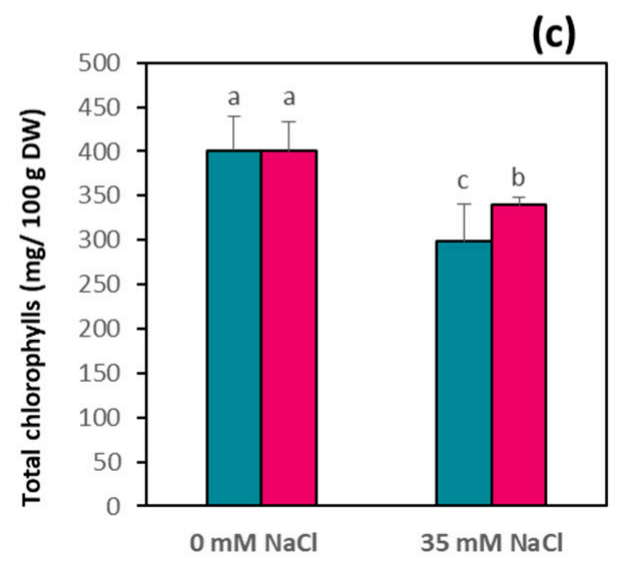

Figure 4. (a) Chlorophyll $a$, (b) chlorophyll $b$ and (c) total chlorophyll concentrations in leaves of pepper plants cultivated under control $(0 \mathrm{mM} \mathrm{NaCl})$ and salinity $(35 \mathrm{mM} \mathrm{NaCl})$ conditions and covered or not with red nets. Bars show the means of four plants with the standard error. Different letters among bars indicate statistical differences according to Tukey's test $(p \leq 0.05)$.

\subsection{Mineral Composition}

Regarding macronutrients, salinity significantly reduced leaf $\mathrm{K}^{+}, \mathrm{P}^{5+}$ and $\mathrm{Mg}^{2+}$ concentrations but no effect of netting was observed in $\mathrm{P}^{5+}$ and $\mathrm{Mg}^{2+}$, whereas $\mathrm{Ca}^{2+}$ was not affected by either salinity or netting (Table 2). Furthermore, netting did not have any effect on $\mathrm{K}^{+}$concentrations under control conditions; however, under salinity, shaded plants presented significantly higher $\mathrm{K}^{+}$concentrations (by $40 \%$ ) than non-shaded plants. For micronutrients, differential trends were observed among ion concentrations. $\mathrm{Fe}^{2+}$ and $\mathrm{B}^{3+}$ concentrations in leaf decreased with salinity, while $\mathrm{Cu}^{2+}$ concentrations were increased by netting under both control and salinity conditions but were not affected by netting (Table 2). Surprisingly, $\mathrm{Mn}^{2+}$ and $\mathrm{Zn}^{2+}$ concentrations increased with salinity in both net treatments but a positive effect of shading on leaf $\mathrm{Mn}^{2+}$ concentrations were observed under salinity. As expected, leaf $\mathrm{Na}^{+}$concentrations significantly increased with salinity in both shaded and net-grown pepper plants (Table 2). Importantly, pepper plants covered with red nets presented significantly lower $\mathrm{Na}^{+}$ concentrations (by 27\%) than non-netted plants under salinity conditions. Therefore, $\mathrm{K}^{+} / \mathrm{Na}^{+}$ratio, despite decreased under salinity, it was significantly higher in pepper plants grown under red nets, especially in salinized plants (Table 2).

Table 2. Cation composition (macronutrients and micronutrients) in leaves of pepper plants cultivated under control $(0 \mathrm{mM} \mathrm{NaCl})$ and salinity $(35 \mathrm{mM} \mathrm{NaCl})$ conditions and covered or not with red nets.

\begin{tabular}{|c|c|c|c|c|c|c|c|c|c|c|c|c|}
\hline \multirow[b]{2}{*}{ Cover $^{1}$} & \multirow[b]{2}{*}{$\begin{array}{c}\text { Salt } \\
\text { Treatment }{ }^{1}\end{array}$} & \multicolumn{4}{|c|}{ Macronutrients (mg.g $\left.{ }^{-1} \mathrm{DW}\right)$} & \multicolumn{5}{|c|}{ Micronutrients (mg.g $\left.{ }^{-1} \mathrm{DW}\right)$} & \multirow[b]{2}{*}{$\mathrm{Na}^{+}$} & \multirow[b]{2}{*}{$\mathrm{K}^{+} / \mathrm{Na}^{+}$} \\
\hline & & $\mathrm{K}^{+}$ & $\mathrm{P}^{5+}$ & $\mathrm{Ca}^{2+}$ & $\mathrm{Mg}^{2+}$ & $\mathrm{Fe}^{2+}$ & $\mathbf{B}^{3+}$ & $\mathrm{Cu}^{2+}$ & $\mathrm{Mn}^{2+}$ & $\mathrm{Zn}^{2+}$ & & \\
\hline Non & $0 \mathrm{mM}$ & $42.370 \mathrm{a}$ & $6.903 \mathrm{a}$ & $42.935 \mathrm{a}$ & $17.020 \mathrm{a}$ & $0.439 \mathrm{a}$ & $0.111 \mathrm{a}$ & $0.002 \mathrm{a}$ & $0.076 \mathrm{~b}$ & $0.016 \mathrm{~b}$ & $0.363 \mathrm{c}$ & $142.540 \mathrm{~b}$ \\
\hline \multirow{2}{*}{ Netting } & $0 \mathrm{mM}$ & $42.938 \mathrm{a}$ & $6.957 \mathrm{a}$ & $44.876 \mathrm{a}$ & $17.168 \mathrm{a}$ & $0.469 \mathrm{a}$ & $0.094 \mathrm{a}$ & $0.001 \mathrm{a}$ & $0.070 \mathrm{~b}$ & $0.017 \mathrm{~b}$ & $0.309 \mathrm{c}$ & $165.687 \mathrm{a}$ \\
\hline & $35 \mathrm{mM}$ & $34.728 \mathrm{~b}$ & $3.464 \mathrm{~b}$ & $40.578 \mathrm{a}$ & $12.978 \mathrm{bc}$ & $0.316 \mathrm{~b}$ & $0.089 a$ & $0.001 \mathrm{a}$ & $0.101 \mathrm{a}$ & $0.030 \mathrm{a}$ & $5.762 \mathrm{~b}$ & $9.582 \mathrm{~b}$ \\
\hline ANOVA $^{2}$ & & & & & & & & & & & & \\
\hline $\mathrm{C} \times \mathrm{S}$ & & * & ns & ns & ns & ns & $\mathrm{ns}$ & ns & ns & ns & ns & ns \\
\hline
\end{tabular}

Data are means of four plants. ${ }^{1}$ Different letters within a column indicate significant differences among treatments $(p \leq 0.05){ }^{2}$ Analysis of variance: ns, not significant; ${ }^{*} p \leq 0.05 ;{ }^{* *} p \leq 0.01 ;{ }^{* * *} p \leq 0.001$.

\subsection{Hormone Concentrations}

Salinity significantly decreased the active $\mathrm{CK}$, $\mathrm{tZ}$, in both shaded and non-shaded plants, while its metabolic precursor, ZR, decreased with salinity only in plants shaded pepper plants and the other active $C K$, iP, was not affected by salinity (Figure $5 \mathrm{a}-\mathrm{c}$ ). Given that absolute concentrations of $\mathrm{t} Z$ and $\mathrm{ZR}$ were much higher than those of $\mathrm{iP}$, total CK concentrations, calculated as the sum of the 
three CKs analyzed, decreased with salinity in both netting treatments (Figure 5d). Importantly, the concentrations of the three CKs and thus total CKs, were significantly superior in netted plants under both control and salinity conditions (by 90 and 20\%, respectively, as total CK concentrations, Figure $5 \mathrm{a}-\mathrm{d})$.

(a)

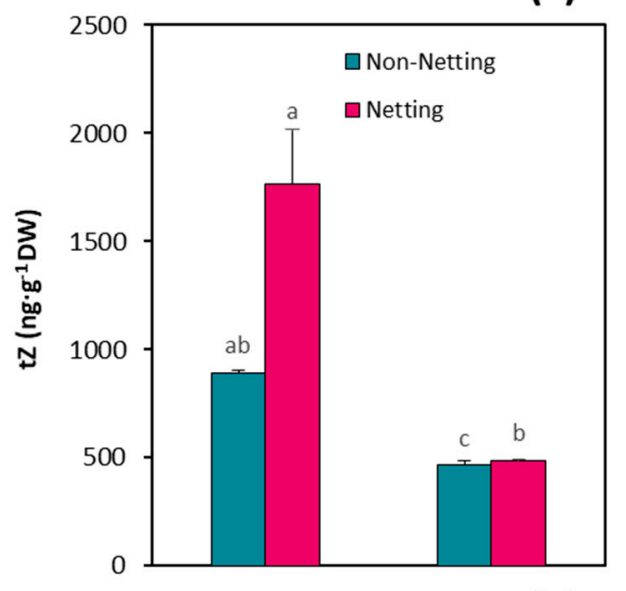

(b)

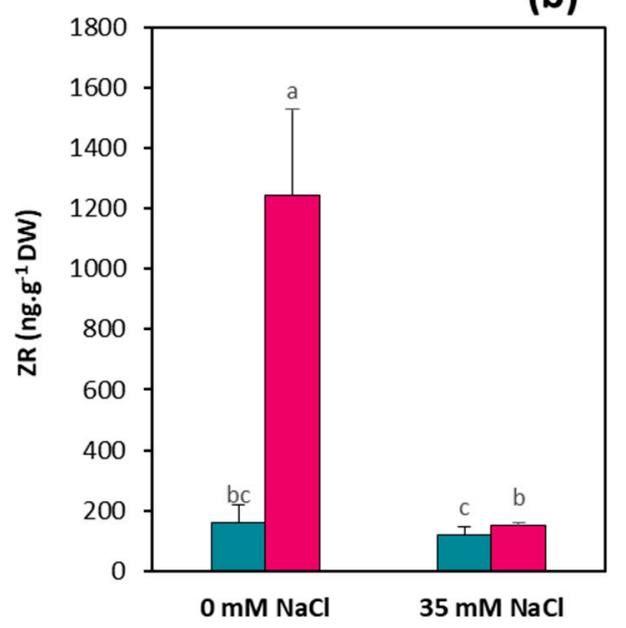

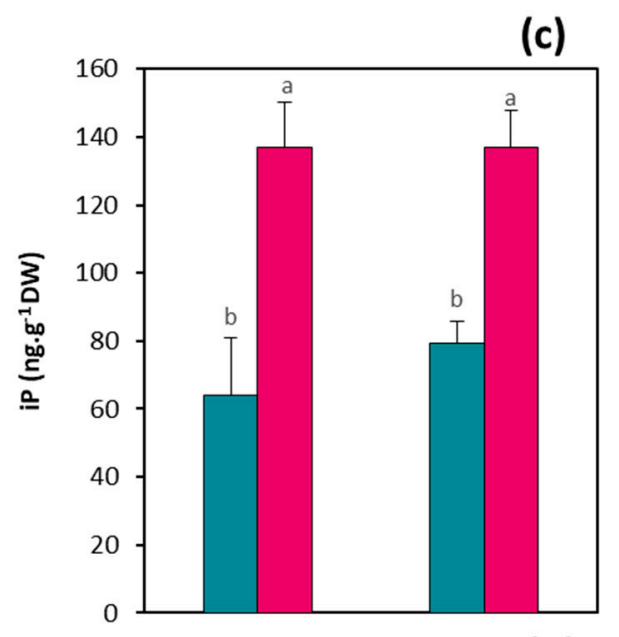

(d)

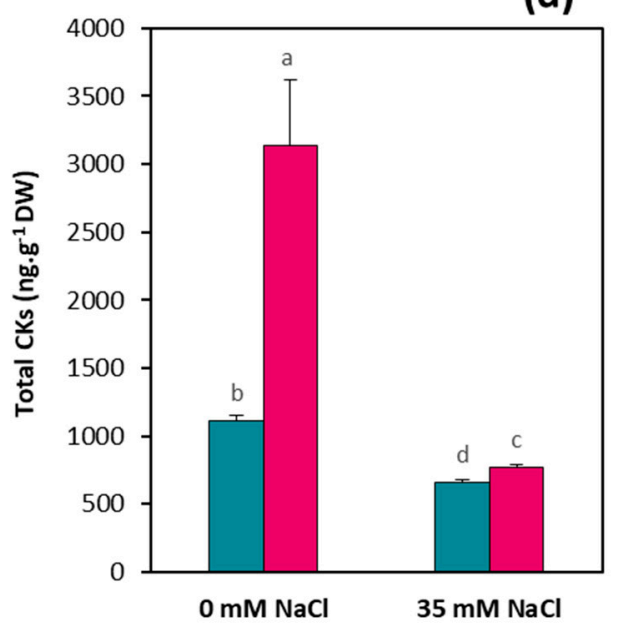

Figure 5. (a) Trans-zeatin (tZ), (b) zeatin-riboside (ZR), (c) isopentenyladenine (iP) and (d) total cytokinin (CKs) concentrations in leaves of pepper plants cultivated under control $(0 \mathrm{mM} \mathrm{NaCl})$ and salinity $(35 \mathrm{mM} \mathrm{NaCl})$ conditions and covered or not with red nets. Bars show the means of four plants with the standard error. Different letters among bars indicate statistical differences according to Tukey's test $(p \leq 0.05)$.

Another important hormonal class, the group of GAs, was also differentially affected in pepper plants by salinity and netting. $\mathrm{GA}_{1}$ and $\mathrm{GA}_{3}$ decreased with salinity, particularly in non-netted plants (Figure 6a,b), whereas $\mathrm{GA}_{4}$ significantly increased with salinity in netted plants (by 6-fold, Figure 6c) but their absolute concentrations were lower. Therefore, total GAs, significantly decreased with salinity in pepper plants grown without netting but did not changed in plants grown under red nets (Figure 6d). Interestingly, all GAs analyzed and thus total GAs, increased in netted plants, with the only exception of $\mathrm{GA}_{4}$ in plant grown under control conditions (Figure 6a-d). 
(a)

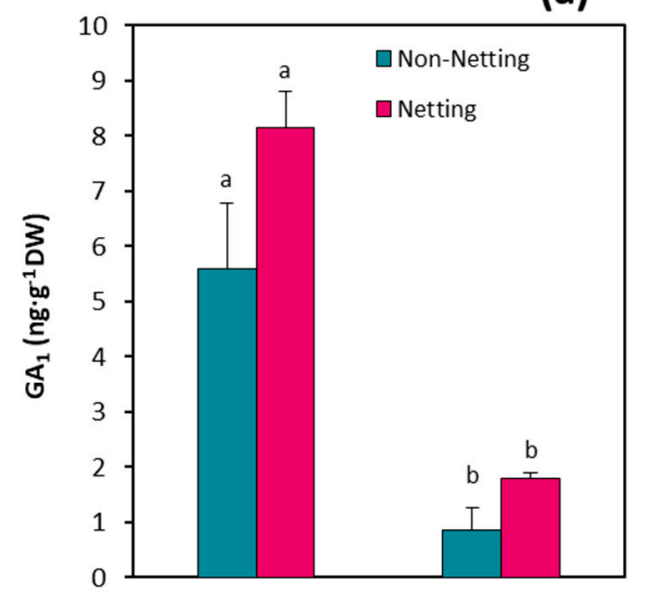

(b)

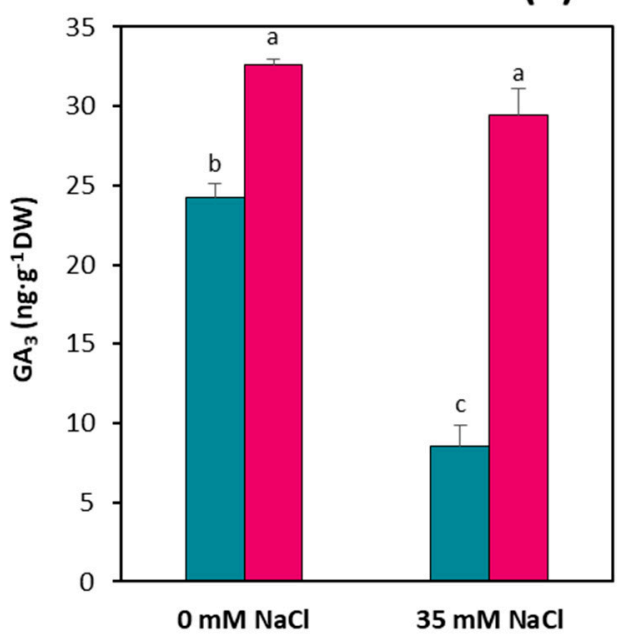

(c)

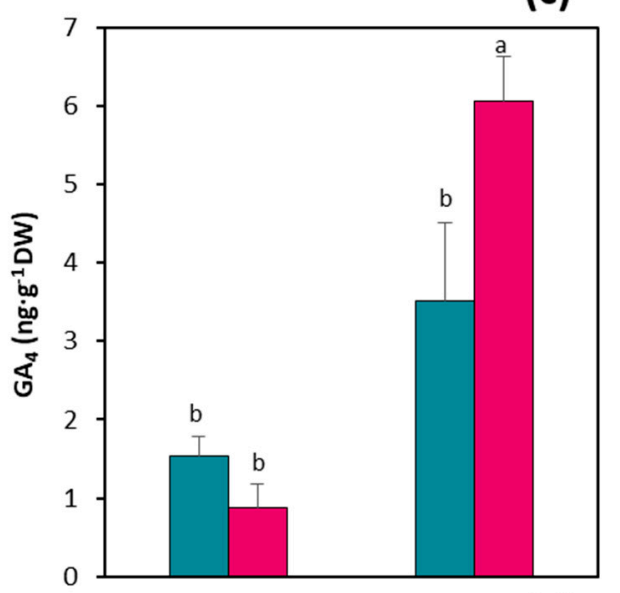

(d)

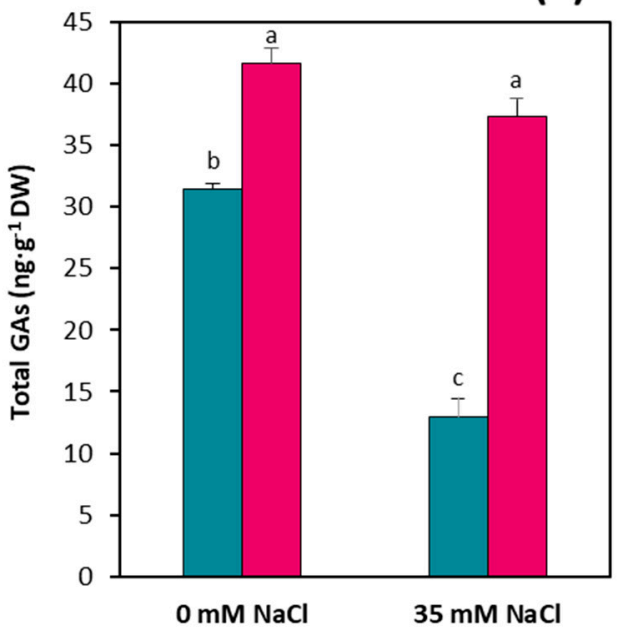

Figure 6. (a) Gibberellin A1 $\left(\mathrm{GA}_{1}\right)$, (b) gibberellin $\mathrm{A} 3\left(\mathrm{GA}_{3}\right)$, (c) gibberellin $\mathrm{A} 4\left(\mathrm{GA}_{4}\right)$ and (d) total gibberellin (GAs) concentrations in leaves of pepper plants cultivated under control $(0 \mathrm{mM} \mathrm{NaCl})$ and salinity $(35 \mathrm{mM} \mathrm{NaCl})$ conditions and covered or not with red nets. Bars show the means of four plants with the standard error. Different letters among bars indicate statistical differences according to Tukey's test $(p \leq 0.05)$.

The most active auxin form, IAA, was also analyzed and their concentrations significantly increased by netting but were not affected by salinity (Figure 7a). In contrast, the classical abiotic stress-related hormone, ABA, significantly augmented with salinity in both shaded and non-shaded plants but it was kept at significantly lower levels in shaded plants (Figure $7 \mathrm{~b}$ ). The concentrations of the ethylene precursor, ACC, also long considered as a "stress hormone," dramatically increased with salinity in plants grown without (by 12 -fold) and with red nets (by 22-fold, Figure 7c). However, netting did not affect ACC concentrations. We also analyzed, two hormones long associated to biotic stresses, JA and SA. SA did not change by salinity treatment but increased in netted plants under both control and salinity conditions (Figure 7d). In contrast, JA significantly decreased with salinity but was not affected by the netting treatment (Figure 7e). 
(a)

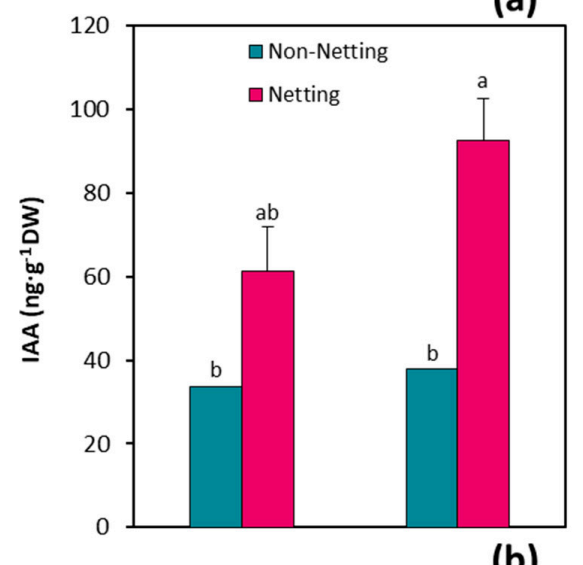

(b)
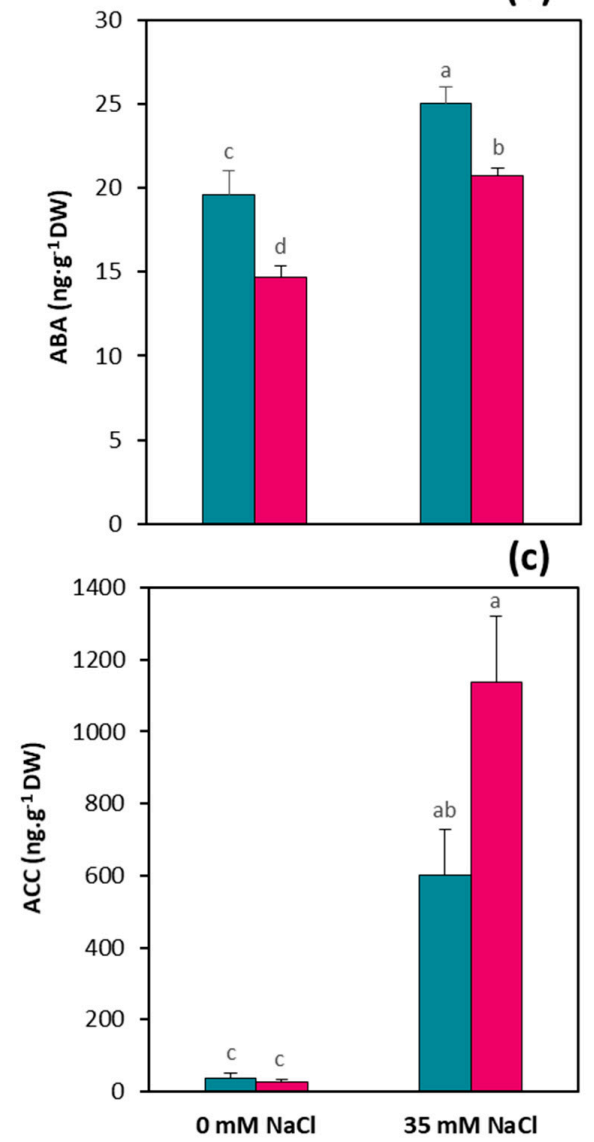

(d)

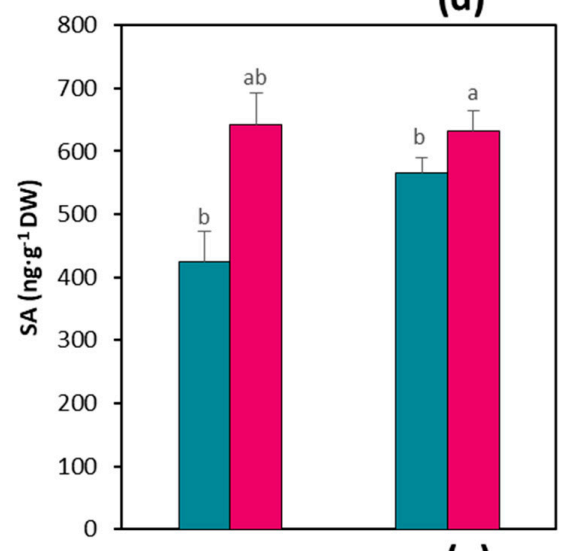

(e)

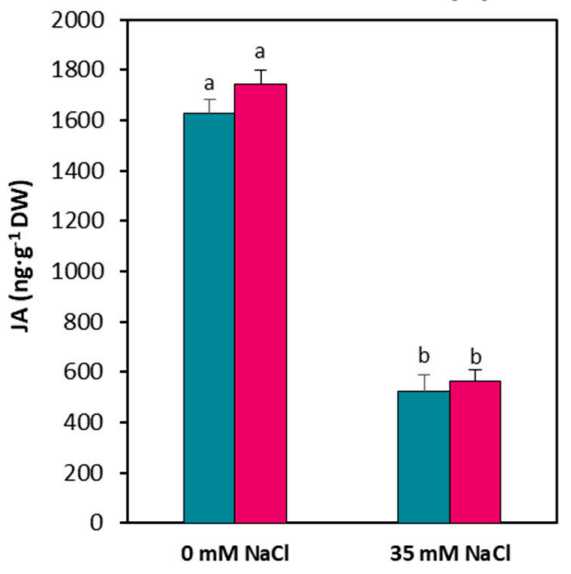

Figure 7. (a) Indole acetic acid (IAA), (b) abscisic acid (ABA), (c) 1-aminocyclopropane-1-carboxylic acid (ACC), (d) salicylic acid (SA) and (e) jasmonic acid (JA) concentrations in leaves of pepper plants cultivated under control $(0 \mathrm{mM} \mathrm{NaCl})$ and salinity $(35 \mathrm{mM} \mathrm{NaCl})$ conditions and covered or not with red nets. Bars show the means of four plants with the standard error. Different letters among bars indicate statistical differences according to Tukey's test $(p \leq 0.05)$.

\subsection{Principal Component Analysis}

To identify important parameters associated to the variability factors used in this study, salinity and red netting, in relation to pepper plant productivity, we performed a loading-PCA with all variables evaluated and leaf mineral and hormonal traits analyzed (Figure 8a), as well as a score-PCA showing the scores in the transformed coordinates of the 4 biological replicates for each treatment (Figure 8b). The loading-PCA uses an orthogonal transformation to convert the evaluated physiological parameters with high autocorrelation into a set of values of linearly uncorrelated variables called 
principal components (PCs). PC1 represented a 49\% and PC2 a 15\% of the population variability, thus accounting both PCs for the largest part of the total variability $(64 \%)$. The prevailing productivity patterns, namely shoot $\mathrm{FW}$ and $\mathrm{CO}_{2}$ assimilation (A), are represented by eigenvectors indicating the strength and direction of the parameter relative to both PCs (Figure 8a). Most growth-related parameters and the photosynthetic rate clustered together with important ionic $\left(\mathrm{K}^{+}\right.$and $\mathrm{K}^{+} / \mathrm{Na}^{+}$ratio $)$ and hormonal ( $\mathrm{tZ}, \mathrm{ZR}$ and total $\mathrm{CKs}, \mathrm{GA}_{1}$ and JA) factors. In another cluster were associated those parameters which co-varied in opposite direction to the productivity parameters, also involving ionic $\left(\mathrm{Na}^{+}, \mathrm{Mg}^{2+}, \mathrm{Fe}^{2+}, \mathrm{Mn}^{2+}\right.$ and $\left.\mathrm{Zn}^{2+}\right)$ and hormonal (ABA and ACC) leaf traits. (Figure 8a). Importantly, the score-PCA clearly grouped the 4 biological replicates of each treatment combination obtained from the two experimental factors (netting and salinity), leading to four differentiated clusters (Figure 8b).

(a)

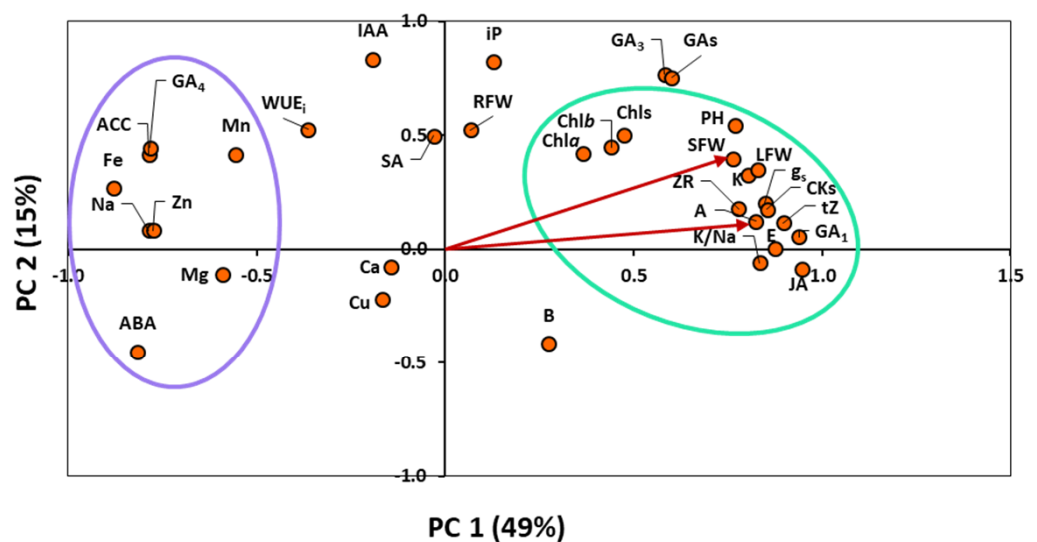

(b)

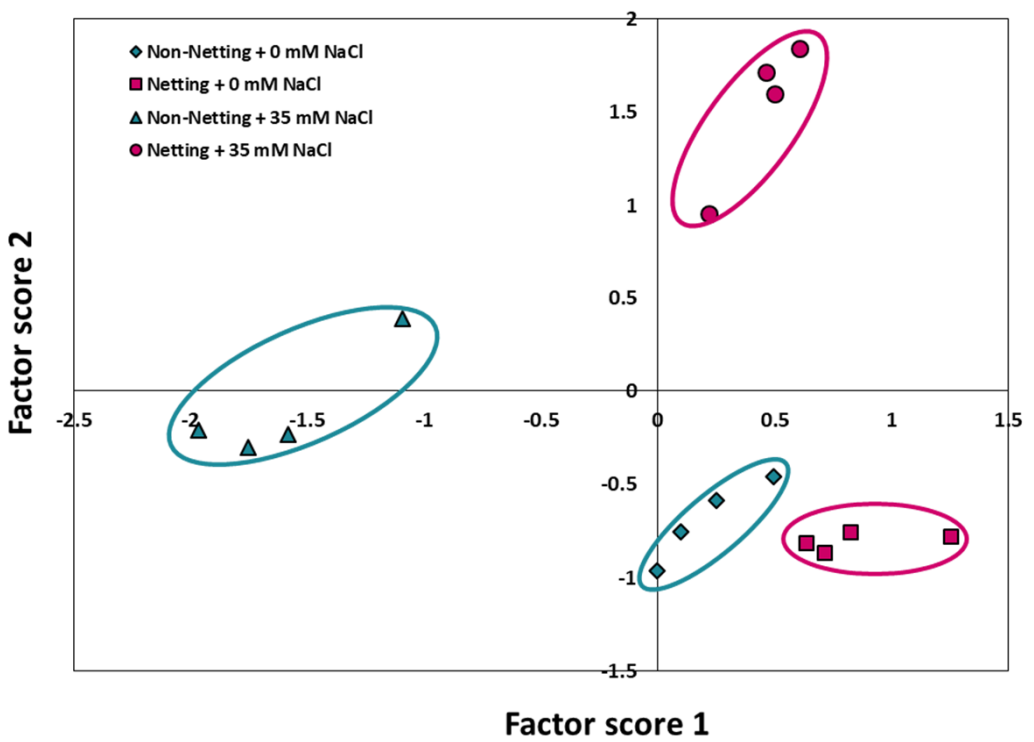

Figure 8. (a) Two axes of a principal component (PC1, PC2) analysis showing the productivity trait vectors (shoot FW, SFW and photosynthetic rate, A) and the loadings of various growth-related, ionic and hormonal variables (denoted by abbreviations) of pepper plants cultivated under control $(0 \mathrm{mM} \mathrm{NaCl})$ and salinity $(35 \mathrm{mM} \mathrm{NaCl})$ conditions and covered or not with red nets. (b) Bi-Plot representing the score values of each biological replicate in the four treatment combinations. Arrows indicate eigenvectors representing the strength and direction of the trait relative to the two PCs and circles enclose those variables/scores which cluster together. SFW: shoot fresh weigh; LFW: leaf fresh weight; PH: plant height; Chla: chlorophyll $a$; Chl $b$ : chlorophyll $b$; Chls: total chlorophylls. 


\section{Discussion}

The agriculture industry is frequently affected by salinity which strongly limits plant productivity. Salinity has been found to disrupt several physiological processes, namely $\mathrm{CO}_{2}$ assimilation, leading to reduction in vegetative growth $[44,45]$. As stated previously, some agro-technological strategies, such as protective and photoselective netting, have been used to cope with abiotic stresses in fruit and horticultural crops and to improve growth performance [26,46,47]. Our study shows that salinity reduced shoot growth-related parameters but shading plants with red nets significantly alleviated salinity effects (Figure $2 \mathrm{a}-\mathrm{c}$ ). This can be in part explained by the reduced temperature and PAR incidence under red nets in the central hours of the day during the growing period (Figure 1). In fact, photoselective netting has proven to modify the micro-climate conditions (temperature, humidity and wind velocity) leading to plant growth and productivity effects [48]. Low light intensities increased stem elongation in tomato plants [49], whereas leaf area, plant growth and photosynthesis have been found to increase with increased shade level in bell pepper due to the reduced leaf and root zone temperatures [50,51]. Importantly, Rajapakse and Shahak [25] suggested a shading rate of $30 \%$ or less as a way to limit thermal impacts on vegetable development, as we used in this study. Furthermore, the use of shading screen alleviated heat stress in 'Herminio' sweet pepper in a winter-summer crop cycle as reflected by better plant vegetative growth and leaf water status [46]. Light regime through photoselective filtration by red netting can also explain the positive growth effects observed in the pepper plants evaluated [25,30].

Additionally, shaded leaves generally have larger total chlorophyll content than leaves from control plants, which can be associated to better photosynthetic status and improved growth. Chlorophyll pigments absorb in the blue $(\sim 430 \mathrm{~nm})$ and red regions $(\sim 660 \mathrm{~nm})$ and thus red netting would increase leaf chlorophyll status and capacity to capture light $[16,22]$. In this study, despite salinity reduced chlorophyll concentrations, salinized pepper plants subjected to red net shading were less affected than non-shaded pepper plants (Figure 4). In previous studies with lettuce, a strong positive correlation of leaf total chlorophyll content with light deficiency was detected [52] and in interaction with nitrogen nutrition [53]. As stated by Beneragama and Goto [54], in a study performed with the shade tolerant algae Euglena gracilis, although shade-grown photosynthetic organs are not directly exposed to sunlight, they produce additional chlorophyll $a$ and $b$ to capture diffuse radiation to produce the carbohydrates needed for the plant to grow. Thus, the extent of modulation of these pigments depends on the species, variety, light conditions and temperature, influencing growth and productivity [15]. Sunlight captured by chlorophyll provides the energy for photosynthesis, thus higher content of chlorophyll of shaded pepper plants under salinity conditions is directly associated to a better performance of the photosynthetic apparatus, as demonstrated by their significantly higher $\mathrm{CO}_{2}$ assimilation with respect to non-shaded plants (Figure 3a). This can be explained by the temperature reduction induced by shading, which might bring net $\mathrm{CO}_{2}$ assimilation rate closer to its optimal temperature range, thus vapor pressure deficit at the leaf surface will decrease. This would lead to increased photosynthesis and stomatal conductance, as proposed in the regulation of drought and salinity stresses [10,45]. Indeed, protective netting have been demonstrated to improve leaf-level photosynthetic light use efficiency, thus reducing photoinhibition symptoms, in 'Honeycrisp' apple under heat stress [47]. Furthermore, light quality manipulation through red nets would help to adjust photosynthesis to stress conditions [55]. Accordingly, sweet pepper leaves of the same age and position were found to respond to light quality manipulation via red netting by increasing net assimilation and stomatal conductance [23].

Increased photosynthetic rate under salinity conditions in shaded pepper plants while stomatal conductance was unaffected resulted in an important improvement of intrinsic WUE (Figure 4a,b,d). Previously, shaded young lemon and apricot trees have been shown to improve WUE through a better control of leaf gas exchange parameters and water relations $[10,12,56]$. It has been long demonstrated that nets reduce turbulence and produce a humid blanket, which contribute to decreasing environmental evaporative demand, thus influencing WUE, which is especially relevant under drought and salinity 
conditions [57]. In fact, our study demonstrated that shading plants with red nets improved leaf water and osmotic potentials as well as relative water content, especially under salinity conditions (Table 1). This can be explained by a higher decoupling of the shaded plants from the atmosphere, particularly under high evaporative demand [12], as shown in apple and peach orchards grown with protective netting, which improved stem water potential with respect to non-shaded orchards [24].

The most detrimental ionic effect of salinity stress is the accumulation of $\mathrm{Na}^{+}$in the plant tissues, provoking severe ion imbalances and thus significant physiological disorders [58]. Although $\mathrm{Na}^{+}$ concentration increased under salinity conditions in the leaves of plants subjected to both netting treatments, thus leading to growth inhibition (Table 2, Figures 1 and 8), shaded pepper plants presented significantly lower leaf $\mathrm{Na}^{+}$levels than the non-shaded ones. This can be explained by an efficient $\mathrm{Na}^{+}$-exclusion mechanism in the roots [59] and/or a dilution effect because of the better water status (Table 1) of pepper plants grown under red nets. Furthermore, high $\mathrm{Na}^{+}$concentration inhibits the uptake of $\mathrm{K}^{+}$, which is an essential mineral nutrient for plant growth and development [58]. This salinity-induced ion imbalance seems to be cushioned by shading salinized plants with red nets, since $\mathrm{K}^{+}$concentrations and the $\mathrm{K}^{+} / \mathrm{Na}^{+}$ratio were significantly higher than those of non-shaded plants (Table 2). Therefore, the increased shoot growth observed in shaded plants under salinity could be partially explained by improved ion homeostasis, as suggests the close association of $\mathrm{K}^{+}$and $\mathrm{K}^{+} \mathrm{Na}^{+}$ with the growth related parameters in the PCA (Figure 8). Previously, it has been demonstrated, using a recombinant tomato population, that productivity-related parameters under salinity were associated to a better regulation of the ion balance of the plant [34], whereas increased $\mathrm{K}$ nutrition has been proven to have ameliorative effects on salinized pepper plants [60,61].

In addition, the reduction in plant growth under salinity conditions could be an outcome of altered hormonal balance. In fact, leaf growth inhibition and premature senescence in salinized tomato plants have been previously associated to decreased bioactive $C K$ concentrations and increased ABA and ACC contents [32,33], as observed in this study. Thus, strategies to increase CK concentrations have been considered to be effective to recover growth and productivity under salinity conditions. For example, engineering tomato rootstocks with a gene encoding the key enzyme of CK biosynthesis, isopentenyl transferase, thus increasing CK concentrations, improved growth and productivity of salinized tomato plants [35]. Importantly, our results show that shading pepper plants significantly increased the concentrations of all bioactive CKs analyzed (Figure 5), closely associated to shoot growth improvement, as demonstrated by their strong linkage within the PCA (Figure 8). This is especially relevant under saline conditions since CK-induced growth and productivity of salinized tomato plants have been previously associated to improved ion homeostasis, particularly of $\mathrm{K}^{+}$and $\mathrm{K}^{+} / \mathrm{Na}^{+}$ratio, stomatal regulation and $\mathrm{CO}_{2}$ assimilation $[34,35]$, as also indicates the close association of these factors with the CK content (Figure 8). GAs have been also studied in relation to their role in regulating growth under salinity stress. In fact, exogenous GA application have been shown to improve growth of tomato plants subjected to salinity through crosstalk with other hormones, particularly CKs [37]. However, in the present study, although GA concentrations of pepper plants showed an important increment by shading, especially under salinity conditions (Figure 6), this was partially uncoupled of shoot growth responses as indicated by the PCA (Figure 8).

The classical stress hormones, ABA and ethylene, have been associated to growth impairment under drought and salinity [62-64]. In fact, our results show an increment in the concentrations of ABA and the ethylene precursor, ACC, in pepper plants grown under salinity conditions (Figure $7 \mathrm{~b}, \mathrm{c}$ ) linked to growth reduction (Figure 2). However, while shading increased leaf ACC concentrations under salinity, decreased ABA. This could explain the improved water status, gas exchange regulation and thus efficiency in the use of water of salinized peppers plants grown under red nets, since ABA has been long demonstrated to control stomatal opening and water relations under stress [65]. Furthermore, SA and JA, despite classically implicated in the defense response of plants against pathogen attack, they have been also considered to play an important role in controlling salinity and drought stress responses in interaction with other hormones, namely ABA $[38,39]$. Our data revealed that SA 
accumulated in shaded plants under salinity conditions (Figure 7d), which could be an adaptive response to salinity thus limiting ABA accumulation, as previously demonstrated by using tomato mutants impaired in hormone biosynthesis [39]. However, SA did not cluster with shoot growth parameters within the PCA (Figure 8), which limits their role in controlling growth under salinity conditions. Concerning JA, an important drop was observed under salinity (Figure 7e), which would explain their clustering very close to the shoot growth in the PCA (Figure 8). However, JA's role in controlling growth of shaded plants under salinity seems to be marginal, since its concentrations did not vary by growing pepper plants under red nets (Figure 7e).

\section{Conclusions}

Salinity stress decreased shoot growth of pepper plants associated with leaf FW and plant height reduction, whereas shading plants with red nets improved growth, especially under salinity conditions. The growth recovery of shaded plants under salinity has been associated to better performance of the photosynthetic apparatus due to improved chlorophyll content and $\mathrm{CO}_{2}$ assimilation. Likewise, stomatal conductance, water relations and thus WUE notably improved by shading. The positive effect of photoselective netting, particularly in salinized plants, can be explained by an efficient mechanism of $\mathrm{Na}^{+}$exclusion, control of ion homeostasis and hormonal balance regulation. A particularly relevant role can be given to $\mathrm{CKs}$, which have been associated to growth control and ion regulation and also to ABA, a master regulator of stomatal opening, which, in crosstalk with SA, lead to a better regulation of water relations in shaded plants. Our results show for the first time that shading plants with red nets modifies plant ion homeostasis and hormonal balance, which could be a strategy to improve growth and productivity under salinity conditions. This is especially important and urgent in the actual scenario of climate crisis, since the most important horticultural areas of the world are suffering severe stress episodes due to reduced quality of both water and soil.

Author Contributions: Conceptualization: A.A., F.M.d.A. and J.L.-M.; methodology: A.G., A.A. and J.L.-M.; formal analysis: A.G. and A.A.; resources: A.A., F.M.d.A. and J.L.-M.; data curation: A.A. and J.L.-M.; writing-original draft preparation: A.A.; writing-review and editing: A.G., A.A., F.M.d.A. and J.L.-M.; supervision: A.A. and J.L.-M.; funding acquisition: F.M.d.A. and J.L.-M. All authors have read and agreed to the published version of the manuscript.

Funding: This research was funded by European Regional Development Fund (ERDF) 80\%—Región de Murcia (FEDER 1420-08).

Acknowledgments: The authors thank Carmen Maxi Rodríguez for technical assistance with field experiments and José Sáez-Sironi and María del Puerto Sánchez-Iglesias for technical assistance with ion and hormone analyses.

Conflicts of Interest: The authors declare no conflict of interest.

\section{References}

1. Jensen, C.R.; Ørum, J.E.; Pedersen, S.M.; Andersen, M.N.; Plauborg, F.; Liu, F.; Jacobsen, S.-E. A Short Overview of Measures for Securing Water Resources for Irrigated Crop Production. J. Agron. Crop Sci. 2014, 200, 333-343. [CrossRef]

2. Ashraf, M.; Harris, P.J.C. Potential biochemical indicators of salinity tolerance in plants. Plant Sci. 2004, 166, 3-16. [CrossRef]

3. Piñero, M.C.; Pérez-Jiménez, M.; López-Marín, J.; del Amor, F.M. Changes in the salinity tolerance of sweet pepper plants as affected by nitrogen form and high $\mathrm{CO}_{2}$ concentration. J. Plant Physiol. 2016, 200, 18-27. [CrossRef] [PubMed]

4. Albacete, A.; Martínez-Andújar, C.; Pérez-Alfocea, F. Hormonal and metabolic regulation of source-sink relations under salinity and drought: From plant survival to crop yield stability. Biotechnol. Adv. 2014, 32, 12-30. [CrossRef] [PubMed]

5. Dajic, Z. Salt Stress. In Physiology and Molecular Biology of Stress Tolerance in Plants; Madhava Rao, K.V., Raghavendra, A.S., Janardhan Reddy, K., Eds.; Springer: Dordrecht, The Netherlands, 2006; pp. 41-99, ISBN 978-1-4020-4225-6. 
6. Zhu, J.-K. Salt and drought stress signal transduction in plants. Annu. Rev. Plant Biol. 2002, 53, $247-273$. [CrossRef] [PubMed]

7. Ghanem, M.E.E.; Martinez-Andújar, C.; Albacete, A.; Pospíšilová, H.; Dodd, I.C.C.; Pérez-Alfocea, F.; Lutts, S. Nitrogen Form Alters Hormonal Balance in Salt-treated Tomato (Solanum lycopersicum L.). J. Plant Growth Regul. 2011, 30, 144-157. [CrossRef]

8. Munns, R.; Gilliham, M. Salinity tolerance of crops-What is the cost? New Phytol. 2015, 208, 668-673. [CrossRef]

9. Yadav, S.; Atri, N. Impact of salinity stress in crop plants and mitigation strategies. In New Frontiers in Stress Management for Durable Agriculture; Rakshit, A., Singh, H.B., Singh, A.K., Singh, U.S., Fraceto, L., Eds.; Springer: Singapore, 2020; pp. 49-63, ISBN 978-981-15-1322-0.

10. Alarcón, J.J.; Ortuño, M.F.; Nicolás, E.; Navarro, A.; Torrecillas, A. Improving water-use efficiency of young lemon trees by shading with aluminised-plastic nets. Agric. Water Manag. 2006, 82, 387-398. [CrossRef]

11. Jifon, J.L.; Syvertsen, J.P. Moderate shade can increase net gas exchange and reduce photoinhibition in citrus leaves. Tree Physiol. 2003, 23, 119-127. [CrossRef]

12. Nicolás, E.; Barradas, V.L.; Ortuño, M.F.; Navarro, A.; Torrecillas, A.; Alarcón, J.J. Environmental and stomatal control of transpiration, canopy conductance and decoupling coefficient in young lemon trees under shading net. Environ. Exp. Bot. 2008, 63, 200-206. [CrossRef]

13. Manja, K.; Aoun, M. The use of nets for tree fruit crops and their impact on the production: A review. Sci. Hortic. 2019, 246, 110-122. [CrossRef]

14. López-Marín, J.; Gálvez, A.; Otálora, G.; del Amor, F.M. Photoselective shade nets for pepper cultivation in southeastern Spain. Acta Hortic. 2019, 1252, 183-189. [CrossRef]

15. Ilić, Z.S.; Fallik, E. Light quality manipulation improves vegetable quality at harvest and postharvest: A review. Environ. Exp. Bot. 2017, 139, 79-90. [CrossRef]

16. Devlin, P.F.; Christie, J.M.; Terry, M.J. Many hands make light work. J. Exp. Bot. 2007, 58, 3071-3077. [CrossRef]

17. Yang, D.; Seaton, D.D.; Krahmer, J.; Halliday, K.J. Photoreceptor effects on plant biomass, resource allocation, and metabolic state. Proc. Natl. Acad. Sci. USA 2016, 113, 7667-7672. [CrossRef] [PubMed]

18. Devlin, P.F. Plants wait for the lights to change to red. Proc. Natl. Acad. Sci. USA 2016, 113, 7301-7303. [CrossRef] [PubMed]

19. Hart, J.E.; Sullivan, S.; Hermanowicz, P.; Petersen, J.; Diaz-Ramos, L.A.; Hoey, D.J.; Łabuz, J.; Christie, J.M. Engineering the phototropin photocycle improves photoreceptor performance and plant biomass production. Proc. Natl. Acad. Sci. USA 2019, 116, 12550-12557. [CrossRef]

20. Singh, S.; Agrawal, S.B.; Agrawal, M. UVR8 mediated plant protective responses under low UV-B radiation leading to photosynthetic acclimation. J. Photochem. Photobiol. B Biol. 2014, 137, 67-76. [CrossRef]

21. Tossi, V.E.; Regalado, J.J.; Iannicelli, J.; Laino, L.E.; Burrieza, H.P.; Escandón, A.S.; Pitta-Álvarez, S.I. Beyond Arabidopsis: Differential UV-B response mediated by UVR8 in diverse species. Front. Plant Sci. 2019, 10, 780. [CrossRef]

22. Rajapakse, N.C.; Shahak, Y. Light-Quality Manipulation by Horticulture Industry. In Light and Plant Development; Whitelam, G.C., Halliday, K.J., Eds.; Blackwell Publishing Ltd: Oxford, UK, 2007; pp. 290-312, ISBN 9780470988893.

23. Kong, Y.; Avraham, L.; Ratner, K.; Shahak, Y. Response of photosynthetic parameters of sweet pepper leaves to light quality manipulation by photoselective shade nets. Acta Hortic. 2012, 956, 501-506. [CrossRef]

24. Shahak, Y.; Gussakovsky, E.E.; Cohen, Y.; Lurie, S.; Stern, R.; Kfir, S.; Naor, A.; Atzmon, I.; Doron, I.; Greenblat-Avron, Y. Colornets: A new approach for light manipulation in fruit trees. Acta Hortic. 2004, 636, 609-616. [CrossRef]

25. Rajapakse, N.C.; Shahak, Y. Light-quality manipulation by horticulture industry. In Annual Plant Reviews Online; Roberts, J.A., Ed.; Wiley Online Library: Oxford, UK, 2018. [CrossRef]

26. Dovjek, I.; Nemera, D.B.; Wachsmann, Y.; Shlizerman, L.; Ratner, K.; Kamara, I.; Morozov, M.; Charuvi, D.; Shahak, Y.; Cohen, S.; et al. Top netting as a practical tool to mitigate the effect of climate change and induce productivity in citrus: Summary of experiments using photo-selective nets. Acta Hortic. 2020, 1268, 265-270. [CrossRef]

27. Shahak, Y.; Yehezkel, H.; Matan, E. Colored shade nets improve production in bell peppers. Gan Sade Vameshek 2006, 4, 37-40. 
28. Santana, J.Q.; Balbino, M.A.; Tavares, T.R.; Bezerra, R.S.; Farias, J.G.; Ferreira, R.C. Effect of photoselective screens in the development and productivity of red and yellow sweet peper. Acta Hortic. 2012, 956, 493-500. [CrossRef]

29. Santos, T.M.; Ferreira, R.C.; Seleguini, A. Growing tomatoes under a red photoselective screenhouse with different management strategies. Acta Hortic. 2017, 1170, 381-388. [CrossRef]

30. Ilić, Z.S.; Milenković, L.; Stanojević, L.; Cvetković, D.; Fallik, E. Effects of the modification of light intensity by color shade nets on yield and quality of tomato fruits. Sci. Hortic. 2012, 139, 90-95. [CrossRef]

31. Mashabela, N.M.; Sivakumar, D.; Soundy, P. Variation in fruit quality in HTSP-5 green bell pepper grown under different photo-selective nets. Acta Hortic. 2016, 1123, 61-68. [CrossRef]

32. Ghanem, M.E.M.E.E.; Albacete, A.; Martínez-Andújar, C.; Acosta, M.; Romero-Aranda, R.; Dodd, I.C.I.C.; Lutts, S.; Pérez-Alfocea, F. Hormonal changes during salinity-induced leaf senescence in tomato (Solanum lycopersicum L.). J. Exp. Bot. 2008, 59, 3039-3050. [CrossRef]

33. Albacete, A.; Ghanem, M.E.; Martínez-Andújar, C.; Acosta, M.; Sánchez-Bravo, J.; Martínez, V.; Lutts, S.; Dodd, I.C.; Pérez-Alfocea, F. Hormonal changes in relation to biomass partitioning and shoot growth impairment in salinized tomato (Solanum lycopersicum L.) plants. J. Exp. Bot. 2008, 59, 4119-4131. [CrossRef]

34. Albacete, A.; Martínez-Andújar, C.; Ghanem, M.E.; Acosta, M.; Sánchez-Bravo, J.; Asins, M.j.; Cuartero, J.; Lutts, S.; Doss, I.c.; Pérez-Alfocea, F. Rootstock-mediated changes in xylem ionic and hormonal status are correlated with delayed leaf senescence, and increased leaf area and crop productivity in salinized tomato. Plant Cell Environ. 2009, 32, 928-938. [CrossRef]

35. Ghanem, M.E.E.; Albacete, A.; Smigocki, A.C.C.; Frébort, I.; Pospisilová, H.; Martínez-Andújar, C.; Acosta, M.; Sánchez-Bravo, J.; Lutts, S.; Dodd, I.C.C.; et al. Root-synthesized cytokinins improve shoot growth and fruit yield in salinized tomato (Solanum lycopersicum L.) plants. J. Exp. Bot. 2011, 62, 125-140. [CrossRef] [PubMed]

36. Albacete, A.; Cantero-Navarro, E.; Balibrea, M.E.M.E.; Großkinsky, D.K.D.K.; de la Cruz González, M.; Martínez-Andújar, C.; Smigocki, A.C.A.C.; Roitsch, T.; Pérez-Alfocea, F. Hormonal and metabolic regulation of tomato fruit sink activity and yield under salinity. J. Exp. Bot. 2014, 65, 6081-6095. [CrossRef] [PubMed]

37. Khalloufi, M.; Martínez-Andújar, C.; Lachaâl, M.; Karray-Bouraoui, N.; Pérez-Alfocea, F.; Albacete, A. The interaction between foliar $\mathrm{GA}_{3}$ application and arbuscular mycorrhizal fungi inoculation improves growth in salinized tomato (Solanum lycopersicum L.) plants by modifying the hormonal balance. J. Plant Physiol. 2017, 214, 134-144. [CrossRef] [PubMed]

38. Carlos, D.O.; Bárbara, H.; Vicent, A.; Aurelio, G.-C. Jasmonic acid transient accumulation is needed for abscisic acid increase in citrus roots under drought stress conditions. Physiol. Plant. 2013, 147, $296-306$. [CrossRef]

39. Muñoz-Espinoza, V.A.; López-Climent, M.F.; Casaretto, J.A.; Gómez-Cadenas, A. Water stress responses of tomato mutants impaired in hormone biosynthesis reveal abscisic acid, jasmonic acid and salicylic acid Interactions. Front. Plant Sci. 2015, 6, 997. [CrossRef]

40. Priel, A. Coloured nets can replace chemical growth regulators. FlowerTECH 2001, 4, 12-13.

41. Ayers, R.S.; Westcot, D.W. FAO Irrigation and Drainage Paper 29 Rev. 1; Food and Agricultural Organization: Rome, Italy, 1985.

42. Machado, R.M.; Serralheiro, R.P. Soil salinity: Effect on vegetable crop growth. Management practices to prevent and mitigate soil salinization. Horticulturae 2017, 3, 30. [CrossRef]

43. Nagata, M.; Yamashita, I. Simple Method for Simultaneous Determination of Chlorophyll and Carotenoids in Tomato Fruit. Nippon Shokuhin Kogyo Gakkaishi 1992, 39, 925-928. [CrossRef]

44. Wungrampha, S.; Joshi, R.; Singla-Pareek, S.L.; Pareek, A. Photosynthesis and salinity: Are these mutually exclusive? Photosynthetica 2018, 56, 366-381. [CrossRef]

45. Chaves, M.M.; Flexas, J.; Pinheiro, C. Photosynthesis under drought and salt stress: Regulation mechanisms from whole plant to cell. Ann. Bot. 2009, 103, 551-560. [CrossRef]

46. López-Marín, J.; González, A.; Pérez-Alfocea, F.; Egea-Gilabert, C.; Fernández, J.A. Grafting is an efficient alternative to shading screens to alleviate thermal stress in greenhouse-grown sweet pepper. Sci. Hortic. 2013, 149, 39-46. [CrossRef]

47. Mupambi, G.; Musacchi, S.; Serra, S.; Kalcsits, L.A.; Layne, D.R.; Schmidt, T. Protective netting improves leaf-level photosynthetic light use efficiency in 'honeycrisp' apple under heat stress. HortScience 2018, 53, 1416-1422. [CrossRef] 
48. Shahak, Y. Photoselective netting: An overview of the concept, research and development and practical implementation in agriculture. Acta Hortic. 2014, 1015, 155-162. [CrossRef]

49. Tinyane, P.P.; Sivakumar, D.; Soundy, P. Influence of photo-selective netting on fruit quality parameters and bioactive compounds in selected tomato cultivars. Sci. Hortic. 2013, 161, 340-349. [CrossRef]

50. Díaz-Pérez, J.C. Bell pepper (Capsicum annum L.) crop as affected by shade level: Microenvironment, plant growth, leaf gas exchange, and leaf mineral nutrient concentration. HortScience 2013, 48, 175-182. [CrossRef]

51. Díaz-Pérez, J.C.; John, K.S. Bell Pepper (Capsicum annum L.) under colored shade nets: Plant Growth and physiological responses. HortScience 2019, 54, 1795-1801. [CrossRef]

52. Kosma, C.; Triantafyllidis, V.; Papasavvas, A.; Salahas, G.; Patakas, A. Yield and nutritional quality of greenhouse lettuce as affected by shading and cultivation season. Emir. J. Food Agric. 2017, 25, 974-979. [CrossRef]

53. Fu, Y.; Li, H.; Yu, J.; Liu, H.; Cao, Z.; Manukovsky, N.S.; Liu, H. Interaction effects of light intensity and nitrogen concentration on growth, photosynthetic characteristics and quality of lettuce (Lactuca sativa L. Var. youmaicai). Sci. Hortic. 2017, 214, 51-57. [CrossRef]

54. Beneragama, C.; Goto, K. Chlorophyll a:b Ratio Increases Under Low-light in "Shade-tolerant" Euglena gracilis. Trop. Agric. Res. 2011, 22, 12-25. [CrossRef]

55. Shibuya, T.; Endo, R.; Kitaya, Y.; Hayashi, S. Growth analysis and photosynthesis measurements of cucumber seedlings grown under light with different red to far-red ratios. HortScience 2016, 51, 843-846. [CrossRef]

56. Nicolás, E.; Torrecillas, A.S.; Amico, J.D.; Alarcón, J.J. Sap flow, gas exchange, and hydraulic conductance of young apricot trees growing under a shading net and different water supplies. J. Plant Physiol. 2005, 162, 439-447. [CrossRef] [PubMed]

57. Allen, L.H., Jr. Shade-cloth microclimate of soybeans. Agron. J. 1975, 67, 175-181. [CrossRef]

58. Ketehouli, T.; Carther, K.F.I.; Noman, M.; Wang, F.-W.; Li, X.-W.; Li, H.-Y. Adaptation of plants to salt stress: Characterization of $\mathrm{Na}+$ and $\mathrm{K}+$ transporters and role of $\mathrm{Cbl}$ gene family in regulating salt stress response. Agronomy 2019, 9, 687. [CrossRef]

59. Wu, H.; Shabala, L.; Azzarello, E.; Huang, Y.; Pandolfi, C.; Su, N.; Wu, Q.; Cai, S.; Bazihizina, N.; Wang, L.; et al. $\mathrm{Na}+$ extrusion from the cytosol and tissue-specific $\mathrm{Na}+$ sequestration in roots confer differential salt stress tolerance between durum and bread wheat. J. Exp. Bot. 2018, 69, 3987-4001. [CrossRef] [PubMed]

60. Kaya, C.; Higgs, D.; Ince, F.; Amador, B.M.; Cakir, A.; Sakar, E. Ameliorative Effects of Potassium Phosphate on Salt-Stressed Pepper and Cucumber. J. Plant Nutr. 2003, 26, 807-820. [CrossRef]

61. Kaya, C.; Higgs, D. Supplementary Potassium Nitrate Improves Salt Tolerance in Bell Pepper Plants. J. Plant Nutr. 2003, 26, 1367-1382. [CrossRef]

62. Sharp, R.E.; LeNoble, M.E. ABA, ethylene and the control of shoot and root growth under water stress. J. Exp. Bot. 2002, 53, 33-37. [CrossRef]

63. Voisin, A.-S.; Reidy, B.; Parent, B.; Rolland, G.; Redondo, E.; Gerentes, D.; Tardieu, F.; Muller, B. Are ABA, ethylene or their interaction involved in the response of leaf growth to soil water deficit? An analysis using naturally occurring variation or genetic transformation of ABA production in maize. Plant Cell Environ. 2006, 29, 1829-1840. [CrossRef]

64. Rosado, A.; Amaya, I.; Valpuesta, V.; Cuartero, J.; Botella, M.A.; Borsani, O. ABA- and ethylene-mediated responses in osmotically stressed tomato are regulated by the TSS2 and TOS1 loci. J. Exp. Bot. 2006, 57, 3327-3335. [CrossRef]

65. Davies, W.J.; Wilkinson, S.; Loveys, B. Stomatal control by chemical signalling and the exploitation of this mechanism to increase water use efficiency in agriculture. New Phytol. 2002, 153, 449-460. [CrossRef]

Publisher's Note: MDPI stays neutral with regard to jurisdictional claims in published maps and institutional affiliations. 